\title{
HISTOPATHOLOGICAL EVALUATION OF CLINICALLY DIAGNOSED PROSTATIC LESIONS.
}

1. MBBS, MS

Associate Professor Surgical Unit-I Peoples University of Medical and Health Sciences for Women Nawabshah.

2. MBBS, MS (Urology) Assistant Professor Urology Peoples University of Medical and Health Sciences for Women Nawabshah.

3. MBBS, FCPS (Urology) Assistant Professor Urology Al-Tibri Medical College and Hospital Karachi.

4. MBBS, FCPS (Urology) Assistant Professor Urology Jinnah Postgraduate Medical Center Jinnah Sindh Medical University Karachi.

5. MBBS, FCPS (Urology) Assistant Professor Urology CMCH Larkana.

6. MBBS, FCPS

Assistant Professor Surgery Al-Tibri Medical College and Hospital Karachi.

Correspondence Address: Dr. Sikandar-e-Azam Yousfani Department of Surgical Unit-I Peoples University of Medical and Health Sciences for Women

Nawabshah.

coolsurgeonpk@gmail.com

Article received on:

06/06/2020

Accepted for publication: 20/08/2020

\begin{abstract}
Sikandar-e-Azam Yousfani' ${ }^{1}$ Aijaz Hussain Memon ${ }^{2}$, Bilal Suria ${ }^{3}$, Arif Ali $^{4}$, Safiullah Sohu ${ }^{5}$,
\end{abstract} Rekha Melwani ${ }^{6}$

ABSTRACT... Objectives: To correlate the clinically diagnosed prostatic lesion with histopathological evaluation, Gleason scoring andserum prostate specific antigen (PSA) levels in a tertiary care centre. Study Design: Observational Study. Setting: The current study was conducted in multiple centers of Sindh like Department of Surgery Unit-III, Peoples University of Medical and Health Sciences, Nawabshah CMCH Larkana, Jinnah Sindh Medical University and Al-Tibri Medical College and Hospital Karachi. Period: January 2018 to December 2019. Material \& Methods: on 112 consecutive cases of clinically diagnosed prostatic disease, all the relevant demographic and clinical details including digital rectal examination (DRE) findings and serum PSA levels were recorded on a proforma designed for the study. PSA values of all these cases were recorded before the surgical procedure. The tissue sample of prostate was collected after surgery and histologically analysed for the confirmation of diagnosis and the Gleason scoring was made. All the results obtained were statistically analysed and tabulated. Results: The age of patients ranged $34-81$ years, with mean age of $58 \pm 3.4$ years. The adenocarcinoma was detected in 05 cases, hyperplasia in 92 cases and hyperplasia with prostatitis in 07 cases. The carcinoma was clinically diagnosed in 17 cases but after histological evaluation, the carcinoma was confirmed in 03 cases and 02 cases of cancer were confirmed among clinically diagnosed cases of hyperplasia. Majority of cases of hyperplasia were having the PSA level $<4 \mathrm{ng} / \mathrm{ml}$ No any case of adenocarcinoma have PSA level below $4 \mathrm{ng} / \mathrm{ml}$, and majority of the cases of denocarcinoma were having PSA level above $20 \mathrm{ng} / \mathrm{ml}$. majority of malignant lesions were having PSA level above $20 \mathrm{ng} / \mathrm{ml}$ and the Gleason score above 6 . No any case of malignancy was detected in those patients having PSA level below $4 \mathrm{ng} / \mathrm{ml}$. Conclusion: The histopathological evaluation with serum PSA levels is necessary in all cases of prostatic disease to rule out the possibility of malignant pathology.

Key words: Adenocarcinoma Prostate, Digital Rectal Examination, Gleason Score, Histopathology, Prostate Specific Antigen.

Article Citation: Yousfani S, Memon AH, Suria B, Ali A, Sohu S, Melwani R. Histopathological evaluation of clinically diagnosed prostatic lesions. Professional Med J 2020; 27(9):1995-2000. DOI: 10.29309/TPMJ/2020.27.09.5463

\section{INTRODUCTION}

There are three primary processes affecting the prostate gland, including inflammation, hyperplasia and tumors, of these the hyperplasia is the most common condition in men over $50 y e a r s$ of age. It occurs frequently with the advancement of age, being considered as a normal aging process. ${ }^{1}$ Prostatic carcinoma is most common cancer in men, the incidence rises $20 \%$ in the age of 50 to $70 \%$ in men between $70-80$ years of age. It is uncommon in Asians, as the diet is becoming more westernized with other lifestyle changes the incidence is increasing nowadays. ${ }^{1-3}$ The American Cancer Society
(ACS) has stated that 1 in 9 men have chances of prostatic cancer in their lifetime, and during the year 2019 , about 174,000 cases of prostatic cancer are estimated among which 31,620 will die due to the disease. ${ }^{4}$ The growth of cancer is slow in majority of cases having a low-grade with relatively low risk and limited aggressiveness. ${ }^{5}$ The digital rectal examination (DRE) and transrectal ultrasonography are considered as the primary practical diagnostic tools for the diagnosis of prostatic malignancy, but having a low specificity and sensitivity. ${ }^{1,6}$ The transrectal biopsy is considered as the final standard for the confirmation of diagnosis. 
Digital rectal examination (DRE) and transrectal ultrasonography are a primary diagnostic tools having a low specificity and sensitivity ${ }^{1,6}$, and the transrectal biopsy is an essential factor for the confirmation of the diagnosis. ${ }^{7}$ Histopathologic assessment can be further confirmed by the use of immunohistochemistry in select cases for the diagnosis and characterization of prostate cancer. $^{8}$

The prostate specific antigen (PSA) is a protein, which is produced by the cells of prostate gland and is nowadays widely used in the diagnosis and management of prostatic cancer. ${ }^{9}$ The PSA has a high predictive value for prostate cancer as compared to DRE or trans-rectal ultrasound sonography (TRUS). ${ }^{10}$

The majority (95\%) of prostatic cancers are adenocarcinomas that develop from the acini of the ducts, the remaining includes the rare histological subtypes like small cell carcinomas, signet ring carcinoma, adenoid cystic carcinoma, neuroendocrine tumor and transitional cell carcinoma. A possible precursor lesion of prostatic malignancy is prostatic intraepithelial neoplasia, which is dysplasia of the epithelium lining the prostatic glands. Studies have shown that the appearance of prostatic intraepithelial neoplasia may precede carcinoma by 10 or more years. ${ }^{11}$

Donald F Gleason in 1966, developed a system of scoring for the histologic grading of prostatic carcinoma, and now with PSA it is important for diagnosis, management, and prognosis of carcinoma, and considered as the best predictor of disease progression and outcome. ${ }^{6,7}$

The Gleason grading method is based entirely on architectural arrangements of prostatic carcinoma. The grading diagram depicting Gleason patterns has undergone modifications from the original diagram. This most current diagram is based on modifications according to a 2014 consensus meeting of the International Society of Urological Pathology (ISUP) published in 2016. ${ }^{12}$
Keeping the all above facts in view, we designed this study to correlate the PSA levels with the histopathological findings and Gleason score in clinically diagnosed cases of prostatic disease.

\section{MATERIAL \& METHODS}

The current study was conducted in multiple centers of sindh like department of surgery unitIII, Peoples University of Medical and Health Sciences, Nawabshah $\mathrm{CMCH}$ Larkana, Jinnah Sindh Medical University and Al-Tibri medical college and hospital Karachi, during January 2018 to December 2019. On 112 consecutive cases evaluated for prostatic disease.

Indications for biopsy were; patients with strong positive clinical history of prostatic illness, elevated PSA level, and or abnormal DRE. Patients already diagnosed and getting treatment for carcinoma of the prostate were excluded from the study.

The relevant demographic and clinical details were recorded on a proforma designed for the study. PSA values of all these cases were recorded before the surgical process and the clinical diagnosis was ascertained. The tissue sample of prostate was collected after surgery and histologically analysed for the confirmation of diagnosis and the Gleason scoring was made. All the results obtained were statistically analysed and tabulated.

\section{RESULTS}

In the current study, 112 clinically diagnosed cases of prostate diseases were evaluated. The age of patients ranged 34-81 years, with mean age of $58 \pm 3.4$ years. Among these 112 cases the adenocarcinoma was detected in 05 cases, hyperplasia in 92 cases and hyperplasia with prostatitis in 07 cases (Table-I). The carcinoma was clinically diagnosed in 17 cases but after histological evaluation, the carcinoma was confirmed in 03 cases and 02 cases of cancer were confirmed among clinically diagnosed cases of hyperplasia (Table-II).

Majority of cases of hyperplasia were having the PSA level $<4 \mathrm{ng} / \mathrm{ml}$ but one case having PSA level above $20 \mathrm{ng} / \mathrm{ml}$ was histologically 
diagnosed as benign hyperplasia. No any case of adenocarcinoma have PSA level below 4ng/ $\mathrm{ml}$, and majority of the cases of adenocarcinoma were having PSA level above 20ng/ml (Table-III).

When we compare the PSA levels with the Gleason score, majority $(3 / 5)$ of cases were having PSA level above $20 \mathrm{ng} / \mathrm{ml}$ and the Gleason score above 6 . No any case of malignancy was detected in those patients having PSA level below 4ng/ml (Table-IV).

\section{DISCUSSION}

The incidence of prostatic lesions is directly proportional with the age of patient. ${ }^{13}$ The integrity of the prostatic tissue is lost by the undergoing various pathological processes, which are responsible for the release of prostate-specific antigen (PSA) into blood circulation, and there is an increase in the serum PSA lavels. ${ }^{14,15}$ The increase in PSA values also depends on upon the differentiation of tumor cells. ${ }^{16}$

\begin{tabular}{|c|c|c|c|c|c|c|}
\hline \multirow{2}{*}{$\begin{array}{l}\text { Age } \\
\text { Group }\end{array}$} & \multicolumn{5}{|c|}{ Histopathological Diagnosis } & \multirow{2}{*}{$\begin{array}{c}\text { Total } \\
\text { Number (\%) }\end{array}$} \\
\hline & Hyperplasia & $\begin{array}{l}\text { Hyperplasia } \\
\text { with Prostatitis }\end{array}$ & Adenocarcinoma & PIN (L) & PIN (H) & \\
\hline $30-40$ & 04 & 01 & 00 & 00 & 00 & 05 (4.4\%) \\
\hline $41-50$ & 16 & 01 & 01 & 01 & 00 & 19 (16.9\%) \\
\hline $51-60$ & 22 & 02 & 01 & 01 & 01 & $27(24.1 \%)$ \\
\hline $61-70$ & 34 & 03 & 02 & 01 & 02 & $42(37.5 \%)$ \\
\hline$>70$ & 16 & 00 & 01 & 01 & 01 & 19 (16.9\%) \\
\hline Total & $92(82.1 \%)$ & $07(6.3 \%)$ & $05(4.4 \%)$ & $04(3.6 \%)$ & $04(3.6 \%)$ & $112(100 \%)$ \\
\hline
\end{tabular}

Table-I. Age distribution according to histological diagnosis

\begin{tabular}{|l|c|c|c|c|c|}
\hline \multicolumn{1}{c|}{$\begin{array}{c}\text { Clinical } \\
\text { Diagnosis }\end{array}$} & $\begin{array}{c}\text { Number of } \\
\text { Cases }\end{array}$ & Hyperplasia & Adenocarcinoma & PIN (L) & PIN (H) \\
\hline Hyperplasia & 95 & 91 & 02 & 02 & 00 \\
\hline Carcinoma & 17 & 08 & 03 & 02 & 04 \\
\hline & 112 & $99(88.4 \%)$ & $05(4.4 \%)$ & $04(3.6 \%)$ & $04(3.6 \%)$ \\
\hline
\end{tabular}

Table-II. Clinical diagnosis with histological diagnosis

\begin{tabular}{|c|l|c|c|c|}
\hline \multirow{2}{*}{ S. No } & \multirow{2}{*}{ PSA Level $(\mathbf{n g} / \mathbf{m l})$} & Hyperplasia & Hyperplasia with Prostatitis & Adenocarcinoma \\
\hline 01 & $<4$ & $78(84.8 \%)$ & $01(14.3 \%)$ & 00 \\
\hline 02 & $\geq 4-10$ & $11(11.9 \%)$ & $05(71.4 \%)$ & $01(20 \%)$ \\
\hline 03 & $11-20$ & $02(2.2 \%)$ & $01(14.3 \%)$ & $01(20 \%)$ \\
\hline 04 & $>20$ & $01(1.1 \%)$ & 00 & $03(60 \%)$ \\
\hline & Total & $92(100 \%)$ & $07(100 \%)$ & $05(100 \%)$ \\
\hline
\end{tabular}

Table-III. PSA level in comparison with histopathological diagnosis.

\begin{tabular}{|l|l|c|c|c|c|}
\hline \multirow{2}{*}{ S. No } & $\begin{array}{c}\text { PSA Level } \mathbf{( n g} / \\
\mathbf{m l})\end{array}$ & Up to $\mathbf{6}$ & Gleason Score & $\begin{array}{c}\text { Total } \\
\text { Up to 7 }\end{array}$ \\
\hline 01 & $>4$ & 00 & 00 & 00 & 00 \\
\hline 02 & $4-10$ & 01 & 00 & 00 & 01 \\
\hline 03 & $11-20$ & 01 & 00 & 00 & 01 \\
\hline 04 & $>21$ & 00 & 02 & 01 & 03 \\
\hline & Total & 02 & 02 & 01 & 05 \\
\hline
\end{tabular}


About $80 \%$ of histologically proven adenocarcinoma have the serum PSA level $>4 \mathrm{ng} / \mathrm{ml}$, and it is evident in $25-30 \%$ with nodular hyperplasia, prostatitis, infarcts, prostatic massage or cystoscopy. It is also documented that the serum PSA level may be normal in prostatic duct carcinomas. ${ }^{17}$ The American College of Preventive Medicine does not recommend routine population screening with digital rectal exam or PSA. ${ }^{18}$ In high risk patients when the PSA level is more than $4 \mathrm{ng} / \mathrm{ml}$, a histological evidences necessary for confirmation of malignancy, since the sensitivity is $100 \%$ rather than PSA more than $10 \mathrm{ng} / \mathrm{ml}$. In the light of no PSA levels being normal and recent recommendation to lower PSA cut-off value to $1.0 \mathrm{ng} / \mathrm{ml}$ to rule out carcinoma. ${ }^{19}$

In current study we detect prostate pathology in 112 cases aged between $34-81$ years with mean age of $58 \pm 3.4$ years, these findings were also observed by other workers. ${ }^{19,20}$ Confirming the documented data we observed hyperplasia in 99 (82.1\%) cases and among them $6.3 \%$ cases were with prostatitis, the hyperplasia was common in 61-70 years age group. ${ }^{9,19}$ We histologically diagnose $4.4 \%$ cases of adenocarcinoma from a total of 112 cases, the reported data incidence is $3.1 \%, 4.8 \%$ and $6.9 \%$ in different studies. ${ }^{21-23}$

The incidence of prostatic cancer varies widely throughout the world, the Americans have the highest and the Asian has the lowest, which may due to dietary habits or racial factors. In western World, the screening facilities are much more better as compare to Asian and specially south Asian countries where lake of awareness, education and poverty play an important role in the low detection rates. ${ }^{24}$

PSA is tissue specific and is not tumor specific, as it was noted in normal, benign, and malignant prostates. We detect no any cancer case with PSA level $<4 \mathrm{ng} / \mathrm{ml}$. It was observed that with the increase in serum PSA levels the detection rate of prostate cancer also increases. There was no any difference in number of cancer patients with PSA levels between 4 to 10 and 10 to $20 \mathrm{ng} / \mathrm{ml}$. Majority of cancer patients have PSA level above $20 \mathrm{ng} / \mathrm{ml}$, our findings were in consistence with the other studies who were also observed the maximum number of cases with PSA level $>20 \mathrm{ng} / \mathrm{ml}^{9}{ }^{9,19}$

The Gleason scoring was done in all cases, and when we compare with the PSA levels, higher grades were observed in tumors having PSA levels above $20 \mathrm{ng} / \mathrm{ml}$, same pattern was also observed by other studies revealing that the high PSA levels are strong indicator of high grade tumors. ${ }^{19,20}$

\section{CONCLUSION}

The current study indicates that histopathological confirmation of malignancy is necessary in all patients having symptoms of prostatic pathology with serum PSA level above $4 \mathrm{ng} / \mathrm{ml}$. it is also evident that the chances of high grade malignancy are more with the advancement of age and PSA level above $20 \mathrm{ng} / \mathrm{ml}$.

Copyright (C) 20 Aug, 2020.

\section{REFERENCES}

1. Epstein Jl, Lotan TL. The lower urinary tract and male genital system. In: Kumar V, Abbas AK, Aster $\mathrm{JC}$, editors. Robbins and Cotran Pathologic Basis of Disease. 9th ed. Philadelphia, Pennsylvania: Elsevier Saunders; 2015.

2. Lalitha K, Suman G, Pruthvish S, Mathew A, Murthy NS. Estimation of time trends of incidence of prostate cancer - An Indian scenario. Asian Pac J Cancer Prev. 2012; 13:6245-50.

3. Kimura T, Egawa S. Epidemiology of prostate cancer in Asian countries. Int J Urol. 2018 Jun; 25(6):524-531.

4. Paddock C. New prostate cancer blood test could reduce biopsies. News Letter. Medical News Today. September 17, 2019. Available from; https://www. medicalnewstoday.com/articles/ 326366.php\#1.

5. Kyriakopoulos CE, Liu G. Chemohormonal therapy for hormone-sensitive prostate cancer: A Review. Cancer J. 2016 Sep/Oct; 22(5):322-5.

6. Goldblum JR, Lamps LW, McKenney JK, Myers JL. Editors. Rosai and Ackerman's Surgical Pathology. 11th edition. 2018. Elsevier.

7. De Lima NG, SoaresDde F, Rhoden EL. Importance of prostate-specific antigen (PSA) as a predictive factor for concordance between the Gleason scores of prostate biopsies and RADICAL prostatectomy specimens. Clinics. 2013; 68:820-4. 
8. Humphrey PA. Histopathology of prostate cancer. Cold Spring HarbPerspect Med. 2017 Oct; 7(10): a030411.

9. Hirachand S, Dangol UMS, Pradhanang S, Acharya S. Study of prostatic pathology and its correlation with prostate specific antigen. J Pathol Nepal. 2017; 7:1074-7.

10. Ahmed MEM, Higazi NZ, Abuidris DO, Idris AA, Khalid $\mathrm{KE}$, Omran M, et al. Prostate specific antigen versus digital rectal examination as screening for ca prostate in Sudanese patients. Sudanese $\mathrm{J}$ Public Health. 2009; 4(2):278-81.

11. Jasani JH, Patel HB, Gheewala B, Vaishnani HV, Bhuva $\mathrm{K}$, Sancheti S, et al. Diagnostic utility of prostate specific antigen for detection of prostate lesions. Int J Biomed Adv Res 2012; 3:268-72.

12. Epstein JI, Egevad L, Amin MB, Delahunt B, Srigley JR, Humphrey PA. The 2014 International Society of Urological Pathology (ISUP) consensus conference on Gleason grading of prostatic carcinoma. The American journal of surgical pathology. 2016 Feb 1;40(2):244-52.

13. Wadgaonkar AR, Patil AA, Mahajan SV, Yengantiwar RP. Correlation of serum prostate specific antigen (PSA) level in various prostate pathology in elderly men. Int J Basic Appl Med Sci 2013; 3:274-81.

14. Gurumurthy D, Maggad R, Patel S. Prostate carcinoma: Correlation of histopathology with serum prostate specific antigen. Int J SciTechnolSoc 2015; 4:1-5.

15. Stimac G, Spajic B, Reljic A, Katusic J, Popovic A, Grubisic I, et al. Effect of histological inflammation on total and free serum prostate-specific antigen values in patients without clinically detectable prostate cancer. Korean J Urol 2014; 55:527-32.

16. National Cancer Institute Surveillance, Epidemiology, and End Results Prostate-Specific Antigen Working Group, Adamo M, Boten JA, Coyle LM, Cronin KA, Lam CJ, Negoita S, Penberthy L, Stevens JL, Ward KC. Validation of prostate-specific antigen laboratory values recorded in Surveillance, Epidemiology, and End Results registries. Cancer. 2017 Feb 15;123(4):697-703.
17. Arora K. Prostate specific antigen (PSA). PathologyOutlines.com website. https://www. pathologyoutlines.com/topic/stainspsa.html. Accessed March 9th, 2020.

18. Lim LS, Sherin K. ACPM prevention practice committee. Screening for prostate cancer in U.S. men ACPM position statement on preventive practice. Am J Prev Med. 2008; 34(2):164-170. doi:10.1016/j. amepre.2007.10.003.

19. Vani BR, Kumar D, Sharath BN, Murthy VS, Geethamala $\mathrm{K}$. A comprehensive study of prostate pathology in correlation with prostate-specific antigen levels: An Indian study. Clin Cancer Investig J 2015; 4(5):617-20. doi: 10.4103/2278-0513.164722.

20. Sinha S, Siriguri SR, Kanakmedala SK, Bikkasani K. Prostate biopsy findings in Indian men: A hospitalbased study. Indian J Cancer 2011; 48:175-80.

21. Bhurgri Y, Bhurgri A, Hassan SH, Zaidi SHM, Rahim A, Sankaranarayanan R, Parkin DM. Cancer incidence in Karachi, Pakistan: First results from Karachi Cancer registry. Int J Cancer. 2000; 85:325-329.

22. Ahmad Z, Idrees R, Fatima S, Uddin N, Ahmed A, Minhas $\mathrm{K}$, Memon A, et al. Commonest cancers in Pakistanfindings and histopathological perspective from a premier surgical pathology center in Pakistan. Asian Pac J Cancer Prev. 2016; 17:1061-1075.

23. Badar F, Mahmood S, Yusuf MA, Sultan F. Epidemiology of cancers in Lahore, Pakistan, 2010-2012: A cross sectional study. BMJ Open. 2016; 6 10.1136/ bmjopen-2016-011828.

24. Chavan PR, Chavan SV, Chavan N R, Trivedi V D. Detection rate of prostate cancer using prostate specific antigen in patients presenting with lower urinary tract symptoms: A retrospective study. J Postgrad Med 2009; 55:17-21. 


\section{AUTHORSHIP AND CONTRIBUTION DECLARATION}

\begin{tabular}{|c|c|c|c|}
\hline Sr. \# & Author(s) Full Name & Contribution to the paper & Author(s) Signature \\
\hline 1 & Sikandar-e-Azam Yousfani & $\begin{array}{l}\text { Conception and design, } \\
\text { Statistical expertise. }\end{array}$ & \\
\hline 3 & $\begin{array}{l}\text { Aijaz Hussain Memon } \\
\text { Bilal Suria }\end{array}$ & $\begin{array}{l}\text { Critical revision of the article } \\
\text { for important intellectual } \\
\text { content. } \\
\text { Data collection. }\end{array}$ & $\beta_{1}$ \\
\hline 4 & $\begin{array}{l}\text { Arif Ali } \\
\text { Safiullah Sohu }\end{array}$ & $\begin{array}{l}\text { Data collection critical } \\
\text { revision, Drafting of the } \\
\text { article. } \\
\text { Data collection. }\end{array}$ & 10 \\
\hline 6 & Rekha Melwani & & \\
\hline
\end{tabular}

